\title{
INFLUENCE OF FUNGAL SPORES BELONGING TO DEUTEROMYCOTINA OVER GROUNDNUT FIELDS IN THE NASHIK DISTRICT OF MAHARASHTRA, INDIA
}

\author{
MALATI H. AHER
}

Head, Department of Botany, K. R. A. College Deola, Nashik, Maharashtra, India

\begin{abstract}
The present aerobiological investigation was carried out in groundnut fields at Makar and Wadi near Deola Tahsil of Nashik District by using volumetric Tilak air sampler kept at a constant height of 2 feet in the center of the groundnut field for two continuous Kharif season during 23-6-13 to 20-9-13 (First Kharif Season) and 11-6-14 to 22-9-14 (Second Kharif Season). Airborne catches trapped over groundnut field include 45 fungal spores, hyphal fragments, insect parts, pollen grains, etc. The spore group Deuteromycotina was found to be dominant and contributed maximum 28 fungal spores followed by Ascomycotina with 10 spore types Zycomycotina with 5 spore types and Basidiomycotina with 2 spore types.

KEYWORDS: Groundnut, Kharif, Deuteromycotina \& Nashik
\end{abstract}

Received: Jan 27, 2021; Accepted: Feb 17, 2021; Published: Apr 27, 2021; Paper Id.: IJBRJUN20217

\section{INTRODUCTION}

Air contains different particles in it; fungal spores, pollen grains, insect parts, bacteria, viruses, dust particles etc. Diversity of organisms depends on environmental conditions. The environment is always dynamic but not static and changes are observed. Aerobiology is the study of dispersion of airborne microorganisms or in other words.

Aerobiology means study of airborne bio-particles (Singh \& Mathur, 2012). Aerobiology is a scientific discipline that, deals with the transport of organisms and biologically significant materials through the atmosphere (Isard and Gage, 2000). The availability and concentration of macro organisms in the air mainly depend on climatic factors such as rainfall, humidity, temperature, wind, velocity, etc. The concentration of air spora may differ according to the availability of substrate (Helfman et al, 2012). The wind velocity is very important for dispersion of spores. Different spores float in wind and travel over long distance. The dispersion of pollutants as well as aerobiological agents is studied in environmental science which becomes a new emerging interdisciplinary branch of science (Tilak et al, 1983: Subba Reddy and Janakibai, 1977).

In the present study, forty five fungal spores, hyphal fragments, insect parts, pollen grains, etc. trapped over the groundnut (Arachis hypogea L.) fields. Deuteromycotina was dominated by the airspora. An aerobiological survey was conducted by employing volumetric Tilak air sampler kept at a constant height of 2 feet in the centre of the groundnut field to find out pathogenic spores, their correlation with the metrological parameters and the growth stages of the crop.

\section{MATERIALS AND METHODS}

Deola is taluka of Nashik District in Maharashtra, India. It is situated on the confluence of the rivers Kolati and Bhawadi. It comes under Dindori Lok Sabha Constituency and Chandwad Vidhan Sabha Constituency. The site for the 
study was a groundnut situated at a distance of $7 \mathrm{kms}$ from Deola. The present study was carried out during the period 236-13 to 20-9-13 (First Kharif season) and 11-6-14 to 22-9-14 (Second Kharif season) by using Tilak air sampler (Tilak and Kulkarni, 1970).

The air sampler was operated continuously for every week for the entire study period. In the present study, aerobiological investigation involved qualitative and quantitative analysis of airspora over groundnut field at Nashik Dist. In Maharashtra state, air monitoring survey was carried out by using Volumetric Tilak Air Sampler (Tilak and Kulkarni, 1970). Tilak Air Sampler was installed in the centre of 1.62-hectare area of a groundnut field and placed on the stool with its orifice facing west and at constant height of 2 feet above the ground level. Tilak Air Sampler is an electrically operated device which has a rotatory drum. The drum completes one rotation in eight days. A cellophane tape has one surface sticky wrapped around the drum while the other surface was smeared with petroleum jelly as adhesive so as to stick spores. Continuous air was sampled at the rate of five (5) litters per minute for a year. After each eight days when the drum completed one rotation, previous cellophane tape was removed and replaced by a new cellophane tape. A cellophane tape was brought to the laboratory and cut into 16 (sixteen) pieces of equal length. Each division provides a qualitative and quantitative data of airborne bio-components of day and night. The slides were prepared and scanned.

\section{RESULT AND DISCUSSION}

Table 1: Yearly Average Mean Concentration and Percent Mean Concentration of Spore Types 23-6-13 to 20-9-13 \& 11-06-14 to 22-09-14 (Total Period of Investigation)

\begin{tabular}{|c|c|c|c|c|c|}
\hline \multirow[b]{2}{*}{$\begin{array}{l}\text { Sr. } \\
\text { No. }\end{array}$} & \multirow[b]{2}{*}{ Spore Type } & \multicolumn{2}{|c|}{ Concentration No. of Spore $\mathrm{m}^{3}$} & \multicolumn{2}{|c|}{ Concentration No. of Spore $\mathrm{m}^{3}$} \\
\hline & & $\begin{array}{c}23-6-13 \text { to } 20- \\
9-13\end{array}$ & $\begin{array}{c}\text { 11-06-14 to } 22- \\
09-14\end{array}$ & $\begin{array}{c}23-6-13 \text { to } 20- \\
9-13\end{array}$ & $\begin{array}{c}\text { 11-06-14 to } 22- \\
09-14\end{array}$ \\
\hline 1 & Alternaria & 34452 & 47544 & 5.92 & 3.41 \\
\hline 2 & Aspergillus & 6974 & 22568 & 1.19 & 1.60 \\
\hline 3 & Beltrania & 17733 & 28798 & 3.05 & 2.04 \\
\hline 4 & Bispora & 31436 & 39284 & 5.40 & 2.79 \\
\hline 5 & Ceratophorum & 2943 & 16296 & 0.50 & 1.16 \\
\hline 6 & Cercospora & 16196 & 32102 & 2.78 & 2.28 \\
\hline 7 & Cladosporium & 14140 & 21336 & 2.43 & 1.51 \\
\hline 8 & Curvularia & 27734 & 26824 & 4.77 & 1.90 \\
\hline 9 & Clasterosporium & 1358 & 11466 & 0.23 & 0.81 \\
\hline 10 & Dictyoarthrinium & 42 & 18774 & 0.007 & 1.33 \\
\hline 11 & Dictyosporium & 294 & 13902 & 0.05 & 0.99 \\
\hline 12 & Diplodia & 17850 & 14126 & 3.07 & 1.00 \\
\hline 13 & Epicoccum & 12166 & 25536 & 2.09 & 1.81 \\
\hline 14 & Exosporium & 6972 & 23030 & 1.19 & 1.64 \\
\hline 15 & Fusarium & 20776 & 24402 & 3.57 & 1.73 \\
\hline 16 & Helminthosporium & 27020 & 46578 & 4.64 & 3.31 \\
\hline 17 & Heterosporium & 11900 & 22022 & 2.04 & 1.56 \\
\hline 18 & Hirudinaria & - & 18004 & - & 1.28 \\
\hline 19 & Harknessia & 3444 & 9576 & 0.59 & 0.68 \\
\hline 20 & Memnonniella & 9842 & 37786 & 1.69 & 2.68 \\
\hline 21 & Nigrospora & 15778 & 22918 & 2.71 & 1.63 \\
\hline 22 & Pestalotia & 10290 & 21616 & 1.76 & 1.53 \\
\hline 23 & Pithomyces & 17192 & 20258 & 2.95 & 1.44 \\
\hline 24 & Pyricularia & 1652 & 12488 & 0.28 & 0.89 \\
\hline 25 & Sirodesmium & 6762 & 25438 & 1.16 & 1.81 \\
\hline 26 & Sporothirx & 616 & 23310 & 0.10 & 1.66 \\
\hline 27 & Tetraploa & 462 & 10052 & 1.07 & 0.71 \\
\hline \multirow[t]{2}{*}{28} & Trichocladium & 532 & 16772 & 0.09 & 1.19 \\
\hline & Total & 316556 & 652806 & 54.327 & 46.39 \\
\hline
\end{tabular}



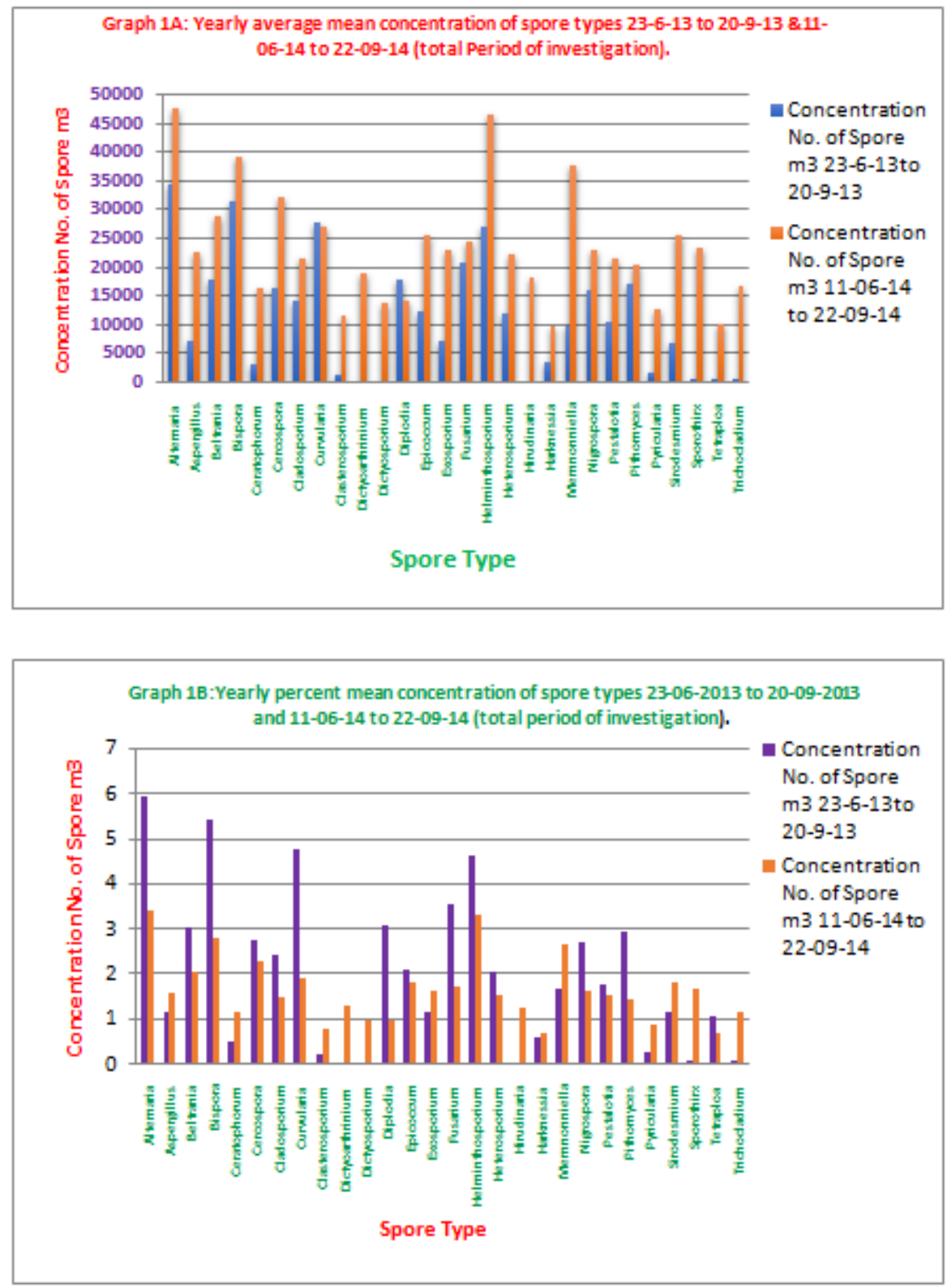

Table 2: Maximum Number of Spore Types of Deuteromycotina during the Investigation Period

\begin{tabular}{|c|c|c|c|c|c|c|c|}
\hline \multirow[b]{2}{*}{ Sr.No. } & \multirow{2}{*}{$\begin{array}{l}\text { Deuteromycotina } \\
\text { Spore Type }\end{array}$} & \multicolumn{2}{|c|}{$\begin{array}{c}\text { Concentration No. of } \\
\text { spore per } \mathrm{m}^{3}\end{array}$} & \multicolumn{2}{|c|}{$\begin{array}{c}\text { Percent mean } \\
\text { Contribution }\end{array}$} & \multirow{2}{*}{$\begin{array}{l}\text { Total spore } \\
\text { conc. Per } \\
\mathbf{m}^{3} \text { of air }\end{array}$} & \multirow{2}{*}{$\begin{array}{l}\text { Percentage } \\
\text { Contribution } \\
\text { to the total } \\
\text { airspora }\end{array}$} \\
\hline & & $\begin{array}{c}23-6-13 \\
\text { to } 20-9-13\end{array}$ & $\begin{array}{c}11-6-14 \\
\text { to } 22-09- \\
14\end{array}$ & $\begin{array}{c}23-6-13 \\
\text { to } 20-09- \\
13\end{array}$ & $\begin{array}{c}11-06-14 \\
\text { to } 22-09- \\
14\end{array}$ & & \\
\hline 1 & Alternaria & 34452 & 47544 & 5.92 & 3.41 & 81996 & 4.15 \\
\hline 2 & Beltrania & 17733 & 28798 & 3.05 & 2.04 & 46531 & 2.35 \\
\hline 3 & Bispora & 31436 & 39284 & 5.40 & 2.79 & 70720 & 3.58 \\
\hline 4 & Cercospora & 16196 & 32102 & 2.78 & 2.28 & 48298 & 2.44 \\
\hline 5 & Curvularia & 27734 & 26824 & 4.77 & 1.90 & 54558 & 2.76 \\
\hline 6 & Fusarium & 20776 & 24402 & 3.57 & 1.73 & 45178 & 2.28 \\
\hline 7 & Helminthosporium & 27020 & 46578 & 4.64 & 3.31 & 73598 & 3.72 \\
\hline 8 & Memnoniella & 9842 & 37786 & 1.69 & 2.68 & 47628 & 2.41 \\
\hline
\end{tabular}




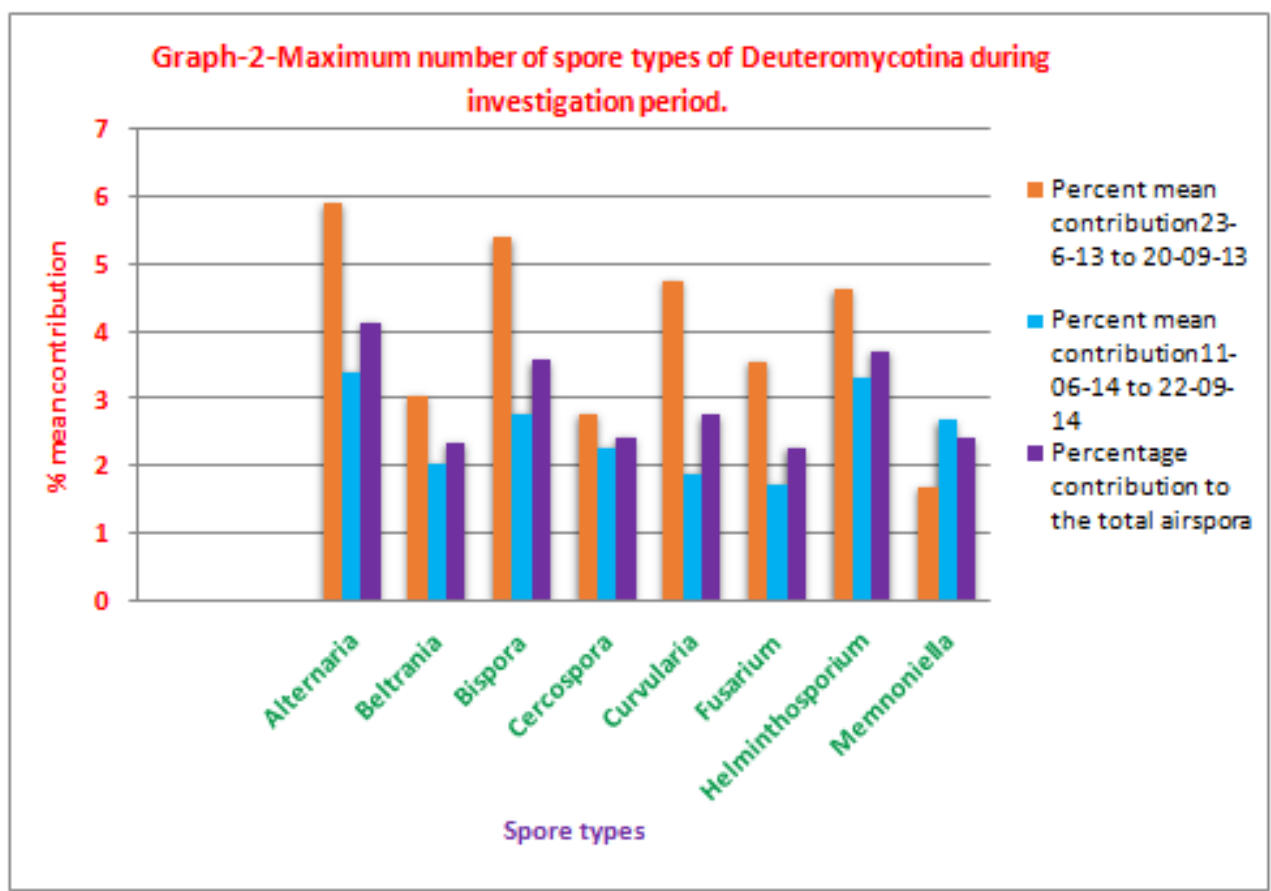

Table 3: Percent Mean and Average Percent Mean Concentration of Spore Groups for the Total Period of the Investigation

\begin{tabular}{|c|l|c|c|c|c|}
\hline \multirow{2}{*}{$\begin{array}{c}\text { Sr. } \\
\text { No. }\end{array}$} & \multirow{2}{*}{ Spore Type } & \multicolumn{3}{|c|}{ Concentration no. of Spore per $\mathbf{~ m}^{\mathbf{3}}$} \\
\cline { 3 - 6 } & \multicolumn{2}{|c|}{$\mathbf{2 3 - 0 6 - 1 3}$ to 20-09-13 } & \multicolumn{1}{|c|}{$\mathbf{1 1 - 0 6 - 1 4}$ to 22-09-14 } \\
\hline 1 & Deuteromycotina & 316556 & 54.327 & 652806 & $46.39 \%$ \\
\hline 2 & Zygomycotina & 22778 & $3.89 \%$ & 140700 & $10.01 \%$ \\
\hline 3 & Ascomycotina & 98293 & $16.85 \%$ & 253344 & $17.99 \%$ \\
\hline 4 & Basidiomycotina & 21822 & $3.75 \%$ & 92694 & $6.58 \%$ \\
\hline 5 & Other types & 581333 & $99.767 \%$ & 1393560 & $99.00 \%$ \\
\hline
\end{tabular}

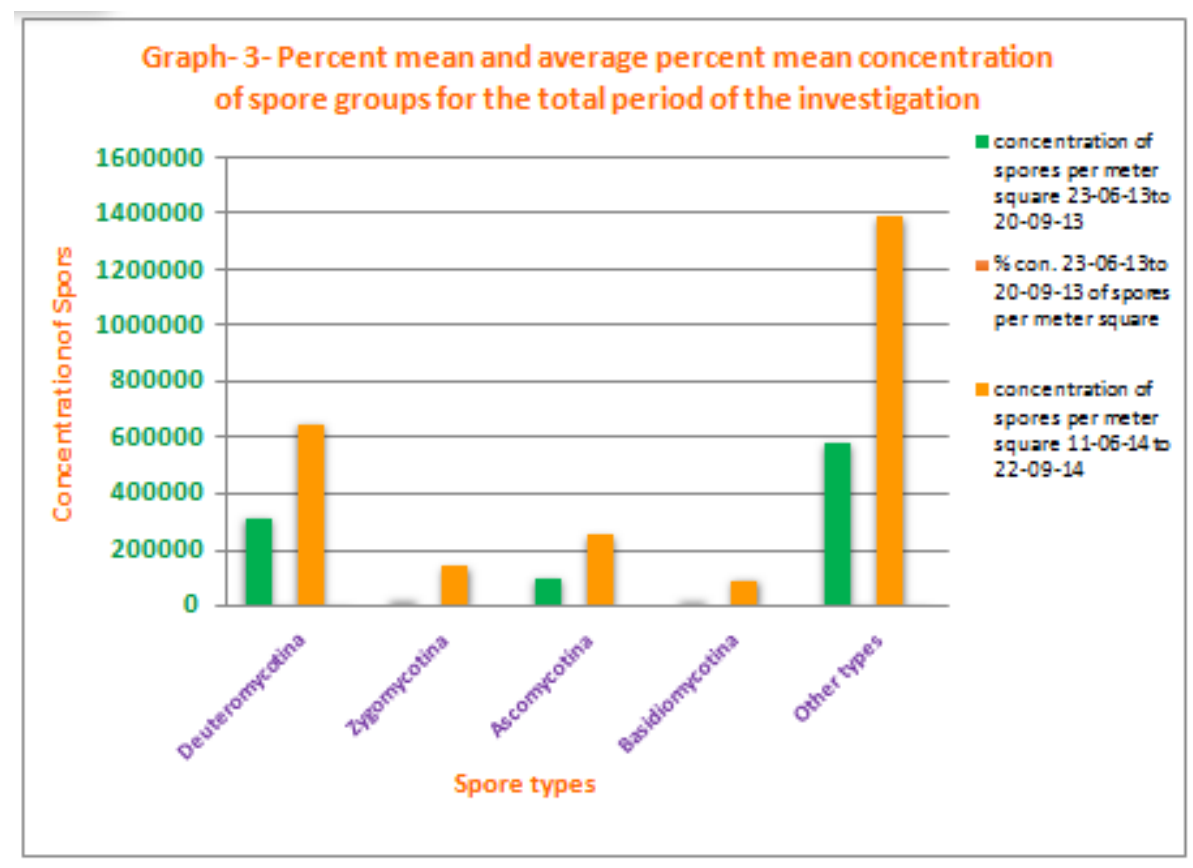


In aerobiological investigation over the groundnut crop (Arachys hypogea L.), JL-24 and SB-11 was carried out during two Kharif seasons 23-06-13 to 20-09-13 and 11-06-14 to 22-09-14 by using Tilak air sampler. In the present study, a total of 45 airborne components are recorded and classified into four groups such as Zygomycotina including five spore types, Ascomycotina contributes ten spore types, Basidiomycotina contributes two spore types and Deuteromycotina contributes twenty eight spore types. It is observed that temperature, humidity, growth and age of plant favour the spread of disease during the months of investigation that is from July to September, humid conditions are present in the air, which are favourable for the spread of disease, but the crop variety grown in the field was found to be highly resistance to the spread of disease.

Deuteromycotina contributed to the maximum percentage during the period of investigation than the other fungal spore groups. It contains a total of 28 fungal spore types to the total airspora. Throughout the period of investigation, percentage contribution to the total airspora of Alternaria was 4.15\%, Beltrania 2.35\%, Bispora 3.58\%, Cercospora 2.44\%, Curvularia 2.76\%, Fusarium 2.28\%, Helminthosporium 3.72\%, Memnoniella $2.41 \%$. The incidence of pathogenic spores noted in the present study is helpful to farmers and cultivators as an alarming situation to them for likely occurrence of fungal diseases, so they can use preventive measures to protect their crops.

\section{REFERENCES}

1. $\quad$ Aher S. K. Thite S. V. and Pande B. N. (2002) Fungal airspora of a groundnut field. Eco. Env. and Cons. 8(3):283-288.

2. Aher S. K. Thite S. V. and Pande B. N. (2004) Aerobiology and Epidemiology of certain diseases of groundnut. J. Curr. Sci., $5(1): 229-232$.

3. Aher S. K., and Pande B. N. (2004) Aerobiological approach to pathogenic fungal spores over groundnut field. Eco. Env. and Cons., 10(1) : 57-59.

4. Arsule C. S. and Pande B. N. (2012) Aeromycology of Cercospora on groundnut at Newasa (M. S.) Internat. J. Plt. Protection 5(1): $8-11$.

5. Arsule C. S. (2013) Fungal Morphotypes contaminants over groundnut fields at Newasa Dist. Ahmednagar (M.S.), New vistas in Plt. Sci. \& Biotech. ISBN978-81-924820-4-0 pp:9-15.

6. Mahadeo Badge, Kalpit Mhatre (2017) Aeromycological Studies over some Paddy Fields in the Ratnagiri District of Maharashtra State in International Journal of Current Research Vol.9, Issue 06, pp: 52441-52444.

7. Sonawane B. N., Arsule C. S. and Pande B. N. (2017) A Survey of Bioaersoles over Groundnut Fields at Newasa Dist. Ahmednagar (M.S.), International Journal of Recent Scientific Research, Vol.8, Issue 8, pp: 18954-18958.

8. Shinde H. P. and Ahire P. P. (2017) Prevalence of fungal spores belonging to Deuteromycotina over Guava (Psidiumguajava Linn.) Orchard in Nashik, Maharashtra, India, Plant Archives Vol.17, No.1, 2017 pp: 55-58.

9. Tilak S. T. (1982) Aerobiological and its practical applications. Proc. I. Nat. Envirn.Bio.33-38. 
